\title{
Inovasi Olahan Pepaya (Abon Pepaya) Guna Meningkatkan Pendapatan Masyarakat Kampung Mekarjaya Desa Padamulya Kecamatan Pasirkuda Kabupaten Cianjur
}

\section{Innovation of Processed Pepaya (Abon Pepaya) To Improve Community Opportunities In Mekarjaya Village, Padamulya Village, Pasirkuda District, Cianjur Regency}

\author{
Siti Sutiati ${ }^{1}$, Tuti Kurnia ${ }^{2}$ \\ ${ }^{1}$ Program Studi Ekonomi Syariah Fakultas Ekonomi Islam Universitas Djuanda Bogor, Jl Tol Ciawi No.1, \\ Kotak Pos 35 Bogor 16720, e-mail: sitisutiaty27@gmail.com \\ ${ }^{2}$ Program Studi Ekonomi Syariah Fakultas Ekonomi Islam Universitas Djuanda Bogor, Jl Tol Ciawi No.1, \\ Kotak Pos 35 Bogor 16720, e-mail: tuti.kurnia@unida.ac.id
}

(Diterima: 25-06-2020; Ditelaah: 25-09-2020; Disetujui: 10-02-2021)

\begin{abstract}
Abstrak
Sumber Daya Alam yang dihasilkan Desa Padamulya sangat melimpah, akan tetapi sumber daya alam yang dimiliki Desa Padamulya belum sepenuhnya dimanfaatkan oleh masyarakatnya, sehingga perlu adanya bimbingan atau pendampingan kepada masyarakat untuk memanfaatkan potensi yang ada. Salah satunya dengan memanfaatkan produk olahan pepaya yang dibuat menjadi sebuah makanan dengan harga nilai jual tinggi. Metode yang dilakukan adalah dengan sosialisasi dan pembuatan inovasi produk olahan pepaya. Dalam pengolahan produk olahan pepaya ini penulis membuat Abon Pepaya yang merupakan makanan cemilan enak dan sehat. Setelah dilaksanakan program ini hasil yang didapatkan adalah pengembangan produk olahan pepaya lebih kreatif dan inovatif serta masyarakat sekitar lebih memahami cara memanfaatkan sebuah potensi yang ada di sekitar.
\end{abstract}

Kata Kunci: Inovasi, Pepaya, Pendapatan Masyarakat

\begin{abstract}
The natural resources produced by Padamulya Village are very abundant, but the natural resources owned by Padamulya Village have not been utilized by the community, so there needs to be assistance or assistance for the community to exploit the existing potential. One of them is by using papaya processed products that are made into foods with high selling prices. The method used is the socialization and manufacture of processed papaya products. In processing this papaya product, the writer makes Abon Papaya which is a delicious and healthy snack food. After the program has been implemented the results obtained are the development of more creative and innovative papaya processed products and the community on how to exploit the potential that is around.
\end{abstract}

Keywords: Innovation, Papaya, Community Income

\section{PENDAHULUAN}

Desa Padamulya terletak diwilayah kecamatan Pasirkuda Kabupaten Cianjur yang merupakan hasil dari pemekaran Desa Girimukti Dusun Cimahpar dan Desa Girijaya Dusun Lingkungsari. Kampung Mekarjaya merupakan salah satu wilayah di Desa Padamulya Kecamatan Pasirkuda yang masyarakatnya banyak bekerja sebagai petani. pepaya merupakan salah satu tanaman yang banyak dibudidayakan di kampung Mekarjaya Desa Padamulya Kecamatan Pasirkuda banyaknya tanaman pepaya ini tentunya menunjukkan bahwa papaya dapat menjadi potensi utama bagi masyarakat Kampung Padamulya Desa 
Padamulya untuk dapat meningkatkan pendapatan masyarakat jika diolah dan dimanfaatkan sebaik-baiknya.

Pepaya mempunyai nilai tambah yang besar karena dapat digunakan sebagai bahan dasar. Di Kampung Mekarjaya pepaya biasanya hanya di makan biasa saja, dan belum ada masyarakat yang membuat usaha olahan pepaya, padahal pepaya ini bisa dibuat menjadi berbagai macam olahan makanan, salah satunya abon pepaya. Masyarakat biasanya tidak pernah menjual pepaya karena disetiap halaman rumah warga kampung mekarjaya terdapat tanaman pepaya, maka jika pepaya ini dibuat menjadi produk olahan abon pepaya dapat meningkatkan harga jual pepaya sehingga meningkatkan penghasilan masyakat setempat. Oleh karena itu dibutuhkan sosialisasi kepada masyarakat tentang cara mengolah pepaya menjadi abon papaya.

Abon pepaya merupakan inovasi produk olahan makanan dari pepaya yang digoreng, sebelum di goreng papaya yang telah diserut dicampurkan dengan bumbubumbu dan tepung lalu bisa memakai bumbu kering sehingga dapat menarik perhatian konsumen mulai dari kalangan anak-anak hingga dewasa. Adapun permasalahan adalah Kampung Mekarjaya membutuhkan upaya pelatihan pembuatan abon papaya sehingga dapat meningkatkan pendapatan masyarakat.

\section{METODE PELAKSANAAN}

Metode pelaksanaan yang dilakukan penulis berupa program pendampingan ekonomi masyarakat dengan cara membentuk kelompok usaha yang akan mengembangkan potensi sumber daya alam yang ada disekitar wilayah desa Padamulya salah satunya adalah Pepaya.

Program produk Abon papaya yang memanfaatkan tanaman pepaya yang melimpah dipedesaan sangat efektif dijadikan sebagai cemilan bahkan oleh-oleh khas daerah tersebut. Dengan adanya pelaksanaan kegiatan pengabdian kepada masyarakat ini bermunculan ide untuk mengembangkan usaha kecil menegah dengan memanfaatkan banyaknya tanaman pepaya kemudian dinamakan Abon pepaya dengan pengemasan menarik sehingga dapat menarik perhatian konsumen dan dapat menaikan tingkat perekonomian masyarakat Kampung Mekarjaya.

\section{1) Survey Lokasi}

Survey lokasi dilakukan langsung ke wilayah Kampung Padamulya Desa Padamulya oleh mahasiswa, hasil yang didapatkan dari survey tersebut bahwa di daerah Kampung Padamulya ini terdapat banyak singkong yang dihasilkan dari kebun.

2) Pendampingan Kewirausahaan Inovasi Produk

Berdasarkan hasil survey tersebut dengan ditemukan banyaknya pepaya yang dihasilkan tersebut menjadi gagasan baru penulis untuk inovasi dan pengembangan produk abon papaya yaitu pepaya tidak hanya dijual dalam bentuk papaya saja tetapi dapat dimanfaatkan juga sebagai bentuk olahan makanan sehingga dapat menambah keragaman makanan khas Kampung Mekarjaya Desa Padamulya dan dapat menambah penghasilan yang didapat selain menjual dalam bentuk mentahan tetapi dapat menjual dalam bentuk olahan. 
3) Sosialisasi mengenai inovasi produk Sebelumdiadakannya pelatihan pembuatan produk abon pepaya, penulis pada tanggal 16 Agustus 2019 melakukan koordinasi kepada ibu-ibu setempat mengenai inovasi produk abon pepaya dan memberitahu bahwa akan ada pelatihan pembuatan produk abon pepaya.

4) Menyediakan kemasan dan bahan-bahan produksiSelanjutnya sebelum pelatihan pembuatan produk, penulis menyediakan kemasan, sticker logo, alat dan bahanbahan yang diperlukan untuk produksi.

5) Pelatihan Produksi

Pelatihan produksi inovasi produk abon papaya ini dihadiri oleh beberapa peserta yaitu ibu-ibu rumah tangga yang tergabung dalam DKM miftahul ulum Kampung Mekarjaya RT 02/08 Kampung mekarjaya.

a) Tanggal 20 Agustus 2019 dilaksanakan pelatihan pertama abon pepaya di posko KKN kelompok 3. Selain pelatihan produksi, dilaksanakan pula pelatihan pengemasan produk abon pepaya agar lebih menarik. Selanjutnya untuk pemasaran, penulis mencoba menjelaskan cara membuat toko online di akun shopee dan cara pemasarannya.

b) Tanggal 24 Agustus 2019 dilaksanakan pelatihan produksi, pengemasan dan pemasaran abon pepaya di rumah Ibu Nani.

c) Tanggal 31 Agustus 2019 dilaksanakan, Pelatihan pemasaran online (shoope).

\section{HASIL \& PEMBAHASAN}

Capaian dari kegiatan pemasaran produk Abon papaya ini pertama, keberhasilan masyarakat dalam melakukan penjualan produk getuk gulung si engkong, dan kedua adalah peningkatan pengetahuan masyarakat terhadap tehnik/metode penjualan, dan terakhir adalah tingginya partisipasi masyarakat dalam kegiatan ini. Kegiatan pengabdian masyarakat yang dilakukan di desa Padamulya yaitu kegiatan produksi yang disertai dengan inovasi melalui pelatihan dan pendampingan dan kegiatan pemasaran dengan pemberian pengetahuan dan praktik langsung. Diharapkan tidak hanya menjadi pengetahuan bagi masyarakat tapi dapat dilanjutkan pada tahapan menjadi sumber pendapatan baru di desa Padamulya.

Antusiasme ini ditunjukkan oleh bebarapa hal antara lain : kegiatan produksi Abon Pepaya ditindak lanjuti dengan kegiatan pemasaran produk. Dalam pemasaran produk abon papaya merupakan bagian dari pendampingan bagi masyarakat terkait dengan proses keseluruhan kegiatan. Kegiatan ini diikuti oleh 10 orang masyarakat. Dalam kegiatan ini masyarakat dibimbing untuk melakukan pemasaran langsung dengan memanfaatkan potensi desa Padamulya.

Masyarakat Kampung Padamulya Desa Padamulya memberikan respon baik terhadap pelaksanaan kegiatan pelatihan pembuatan Abon pepaya kegiatan ini berjalan dengan lancar. Jumlah masyarakat yang hadir dalam kegiatan pelatihan ini berjumlah 10 orang sehingga dengan adanya partisipasi masyarakat tersebut menjadikan program ini terlaksana sesuai dengan perencanaan awal. 
Pelatihan dilakukan sebanyak 2 kali di dua tempat masing-masing 1 kali di kampung Padamulya. Jumlah peserta yang mengikuti pelatihan berkisar 20-30 orang ibu rumah tangga. Setelah dilakukan pelatihan maka dilakukan pendampingan kepada peserta pelatihan. Hal ini dilakukan agar kegiatan berlangsung efektif dan berkelanjutan sehingga tujuan peningkatan pendapatan masyarakat dapat tercapai. Pendampingan dilakukan 1 minggu 1 kali selama 1 bulan. Hasil dari kegiatan pengabdian ini berupa produk "Abon Pepaya" yang dihasilkan oleh masyarakat tentang pemanfaatan pepaya sebagai salah satu inovasi produk untuk meningkatkan pendapatan masyarakat. Antusiasme masyarakat dalam kegiatan ini, menjadi faktor pendorong yang mampu memperlancar kegiatan ini.

\section{KESIMPULAN}

Berdasarkan hasil kegitan PKM yang telah dilaksanakan di Desa Padamulya,Kecamatan Pasirkuda, Kabupaten Cianjur, masyarakat menyadari dan memahami bahwa perlunya inovasi dan kreatifitas dalam pengelolaan potensi hasil alam. Kegiatan pemanfaatan papaya sebagai inovasi pembuatan Abon Pepaya ini diharapkan dapat menjadi pemacu kreatifitas masyarakat dalam pengolahan hasil alam dan mampu menggerakkan perekonomian serta meningkatkan kesejahteraan masyarakat desa.

\section{DAFTAR PUSTAKA}

Maesaroh, S. Kurnia, T (2018). Program Peningkatan Pendapatan Masyarakat Desa Melalui Pemanfaatan Limbah Kulit Pisang Menjadi Produk Kulit Pisang Aneka Rasa (Vol 5 No 2 Edisi Oktober 2018 p-ISSN 2442-3726 e-ISSN 2550-1143) Page 125. 